$\xi=-1$

\title{
The Role of Social Worker in Developing Information Needs among Street Children (A case study in Surabaya Indonesia)
}

\author{
Fitri Mutia \\ ${ }^{1}$ Faculty of Social and Political Sciences University of Airlangga, Indonesia, \\ *Corresponding author E-mail: fitrimutia0210@gmail.com
}

\begin{abstract}
Information needs among children is interesting topic because the way they looking for information are difference with adult. Usually children require assistance from certain person to help them finding the right and valid information. In the case of street children who living in social institutions, social worker role is very important to help then finding information because most of street children have no formal education, so they need to directed at finding and retrieving information to develop their knowledge. The number of street children in Surabaya increasing every year, this condition forced Surabaya Social Service to implement appropriate strategies to reduce the problems related to street children. Ones were through the assistance from the Regional Technical Implementation Unit (UPTD) "Kampung Anak Negeri" staff in Surabaya. The aim of this research is to describe the role of social worker in developing information needs of street children in UPTD Surabaya. Data in this research was collecting using questionnaire. The research method is quantitative descriptive with total population (32 people) become respondent, consisting of all street children (15 children) and social worker (17 person) in UPTD "Kampung Anak Negeri" Surabaya. The result show that social worker in UPTD Surabaya have a potential role in developing information needs among street children, especially when they playing as facilitator and educator roles. Social worker support street children to find information that as many $9(60 \%)$ street children mostly need information related to their hobbies (such as music, sports). Around $13(76.5 \%)$ social workers provide an opportunity for them to disclose that information, and for more aware and independent in the process of finding information $12(70.6 \%)$ social worker teaches street children a strategy to obtain appropriate information like visit the library or using the internet (with permission). According to $12(70.6 \%)$ social worker, the ability of street children to finding information is still dependent on social worker role as facilitator and educator. But, the social worker role as community representatives and technical, become a supporting role for the success of finding information that street children needs..
\end{abstract}

Keywords: Social Worker Role, facilitator and educator roles, Information Needs, Street Children, UPTD “Kampung Anak Negeri” Institutions.

\section{Introduction}

The phenomenon and the spread of street children become one of social problems that quite complicated for Indonesia. As we know, all children are generations which need to be protected including the street children. The attention from the competent parties should be given for them because it is their rights for a serious treatment then get a better live. According to Sutarso from Data Science Indonesia [1], stated that the problem of street children can't be separated from a variety things such as the structural poverty in the society, the more limited space for children to play as the impact of city development, family life not in harmony either due to divorce or the presence of a step father or step mother, poor parents that can't effort their children's education, and economic pressures which make poor families increasingly marginalized so all these problem force each family member to support themselves.

Based on data from the Indonesia Ministry of Social [2], there are 94.674 street children in Indonesia, increase $64 \%$ of street children in $2002-2008$ or an average about $10.6 \%$ per year. Using that assumption (increase $10.6 \%$ every year), at the end of 2015 estimated 300.000 street children in Indonesia. Another data from Social Ministry [3] informed that street children in 2016 become 4.1 million (Jawapos.com, 2016). Unfortunately in east java (especially Surabaya), there is no exact number of street children, there are only data about abandoned children (age around 5-17 years) which is considered to have the same living conditions with street children as much as 248.665 persons (Central Bureau of Statistics of East Java Province, 2012) [4].

Street children are children whose activity of life much more spent on the streets. The phenomenon of street children in the city of Surabaya very rarely from abandoned children or have no family. They mostly still have parents and a place to live, but can't afford to pay for everyday life. To help the needs of their family, street children usually sell newspapers, become a street vendor or doing other informal jobs with minimum wages (dependent on service user kindness). In community, the existence of street children often disturbing the peace in public places, have related to their stereotype or a negative view that has been embedded in the minds of people about them. That condition has forces Social Service of Surabaya City to reduce the number of street children through assistance activities in UPTD institution.

Substantially, protection the human rights of street children are similar with the people rights in general. As part of the future generation, even though the street children were classified as problematic social communities, they also have rights like other children, for example to earn health facilities, education, recreation and protection, also to find information and knowledge. The availability of information which requered by street children should be facilitated by many parties like government, social organizations which engaged in services for street children, as well as by the surrounding community where the street children 
live. In fact, the government efforts to build information society led the society easier to access information than everybody will get the usefulness and benefits of the information. Along with the widespread development of information technology, people have the ability to utilize information and make the information as added value to improve their quality of life. All information should be obtained by street children through various systems of formal or informal assistance, so that they can be independent, play an active role in national development or even involved in the world development through their knowledge. In this case, the Government of Surabaya City through the Social Welfare Department has an active role in fostering street children by implementation the rules from Mayor of Surabaya No. 61/2012 on Social Service of Surabaya City [5].

UPTD "Kampung Anak Negeri" is a special social welfare service for street children, juvenile delinquents and abandoned children in Surabaya. This institution was established to seek creative education program which suitable for street children future live, so they are no longer living on the streets and have a better live. Assistance to street children which conducted in UPTD is intended to foster and improve a better and positive behavior of street children, as well as provide skills training in accordance with the talent of street children so that they can return to the society and does not living in the streets again. In general there are some program in UPTD, namely; 1) mental and spiritual guidance, 2) physical guidance, 3) social assistance, 4) interest or skills counseling, and 5) cognitive counseling.

As most street children have no formal education in school, the role of social worker is very important to assistance them to finding and retrieving information and develop their knowledge. For adult person, finding and retrieving the right information is not difficult, but for children (on this case street children) would be different. Children need assistance from certain parties so they can easily, quickly and accurately find information they needed. Through those programs, social worker in UPTD seeks to improve the knowledge and skills of street children so in the future they can live independently in the community.

\section{Literature Review}

In this research, there are several concepts would be discussed which are role of social worker, information needs, and the concept of street children. All concepts are described below.

\section{a. Role of Social worker}

Social worker can be referred as agents of change who give assistance and involved to help street children solve their problems through some program. This assistance is a dynamic interaction between street children and social worker in UPTD to jointly deal with everyday problems faced by street children. On the other hands, assistance is crucial for the government to determine whether their program in handling street children success or not. According to the Ministry of Social Affairs, in general the role of social worker covers 4 main roles, namely as facilitators, educators, community representatives and technical roles for community that they accompany. Below are descriptions of each role [6].

1) Facilitator; a role with regard to the provision of motivation, opportunity, and support for the community. Some of the tasks associates with this role include being a model, mediation and negotiation, support, consensus-building, as well as organizing and resource utilization.

2) Educators; social worker plays an active role as an agent that gives positive and directive feedback based on their knowledge and experience, as well as exchange ideas with the knowledge and experience of the community that they accompany. Raising awareness, conveying information and engage in confrontation, training for street children are some of the tasks associated with this role.
3) Representatives of the community; social worker interact with external agencies on behalf of and in the interest of the assisted communities. They have to finding resources, media, community relations, and to build networks.

4) Technical roles; refers to the application of practical skills. social worker are required not only be able as "change manager" who organize the group, but also capable to performing technical tasks in accordance with the basic skills, such as analyzing the social, managing group dynamics, establish relationships, negotiation, counseling, search and manage source of funds.

\section{b. Information needs}

In the case to develop information needs of street children, social worker must aware the needs of street children about certain information then try to perform efforts to link the situation where street children needs specific information with their experience in the past related to information retrieval. The information could be sought by the street children through informal discussions, determining the appropriate resources to helping children find information in accordance with their interests, as well as provide an alternative way of finding information through appropriate media. Besides that, social worker directing street children on the type of information needed to consider several criteria for example, if the children needs information about school project, social work have to considering a prerequisite that must be met so that the task can be completed on time, suggest sources of information, then choose accurate and accessible media to find the information.

Sometimes street children does not understand the scope of their information needs, how to find information, even they feel pessimistic about the possibility of obtaining the information would be in accordance with their needs. In this situation, social worker together with an intermediary agent in UPTD (peer social worker/expert and librarians) try to children by providing an appropriate strategy how to choose information more systematically, suggested the use of the certain media that has a great chance to find the information needed, and consider the location where information can be found easily.

Efforts to assess information for children is not as easy as adults, because there are several aspects that affect children ability to find the exact information such as their level of biological growth, their information literacy level, economic status, and permit that must be obtained from older person (parents, teacher) when accessing certain resources from certain media [7-8].

c. Street Children

Street children are defined as children around 6-18 years vulnerable working on the streets, or children who have been working on the streets, or children who working and living on the street. They utilize most of their time to perform daily activities on the streets include in the market environment, shopping centers and other crowded [9].

Generally street children divided into three groups, first, children on the street; children who have economic activities (child labor) on the street but still has a strong relationship with their parents. Street children in this category serves to help strengthen the economy of their family because of the burden can't be resolved by both parents. Second, children of the street; children who participate fully in the streets (social and economic), they have relate to their parents but the frequency of meetings very erratic and some reason (usually violence) or run away from home. Third, children from families of the street; children who come from families who live on the streets. They have a pretty strong family ties, but life from one place to another, living on the streets since he was a baby (in the womb) or under a bridge, wild house along the railroad tracks, and so on [10].

As we know, the life challenges for street children are different from a normal child's life in the community. Street children often live and thrive under pressure and stigma as intruder and no favor to them. So, behavior that street children show usually reflection of the way society treats them as well as community expectations 
on their behavior. Alternative models of handling street children can be done through four ways [2]:

1) Street-centered intervention; handling of street children which centered on the "street" where street children usually worked. The goal is to reach and serve children in their immediate environment (in the street).

2) Family-centered intervention; handling street children focused on the provision of social assistance or family empowerment to prevent children from becoming street children or attract street children return to their families.

3) Institutional-centered intervention; handling of street children concentrated in institutions (nursing), temporarily (preparing reunification with their families) and permanent (especially if the street children had no parents or relatives). This approach also includes providing temporary shelter and hostel facilities of adaptation institution for street children.

4) Community-centered intervention; handling of street children which was centered in a community. Involving community development programs to empower or strengthen the capacity of social institutions in the community to establish a network through various agencies both government agencies and civil society organizations including the Corporate Social Responsibility.

For Surabaya city Government, the aims to establish the UPTD "Kampung Anak Negeri" as institutional-centered intervention are to reduce the number of street children, improve the quality of their education to eliminate crime in society, and to create independence for them. UPTD try to educate children who are at school age by managing some skill program in that institution and also by defraying formal education. For example UPTD institution working together with Kedung Baruk 1 junior high school, Surabaya 19 senior high school and Surabaya PGRI 1 vocational school, to give children formal education. UPTD also fulfill daily financial for each children and also monthly schools fee. If street children don't want to follow the formal education, they can choose various program/training that provided by UPTD. For example, sports programs (cycling), traditional martial arts, mental and spiritual training, arts (music, painting), agriculture, English course, as well as exploring their interests and talents (sewing, repairing motor cycle machine and dynamo). Street children can stay in this UPTD institution until they are 18 years old or until graduating senior high school and after that, they have to live independently outside the institution.

\section{Research Methods}

This research type is descriptive quantitative, which aimed to investigate the circumstances, conditions, or other things that the results presented in the form of research reports [11]. As we also know that descriptive studies portray a number of variables relating to problems or units studied, tend to describe a phenomenon as it is a way to examine regularly-tight, give priority to objectivity, and absence of a given treatment or controlled absence hypothesis testing [12].

This research was conducted in the only one social institutions administered by government of Surabaya City (UPTD "Kampung Anak Negeri). Data collection done by giving questionnaire to the social worker and street children, beside that researcher also make an observation about the location and interview with some respondent. The populations on this research are 32 persons, consisting of 17 social worker and 15 street children who live in UPTD. All the populations are become informant in this research.

\section{Result and Discussion}

In this research, the characteristics of social worker and street children in UPTD were identified by sex, age, and education level. From 17 social workers, 15 persons $(88.2 \%)$ are male, and 2 per- sons $(11.8 \%)$ are female. They around $26-30$ years old $(41.2 \%)$ and undergraduate education level 10 persons $(58.8 \%)$. For street children, all of them were male (15 children or $100 \%)$, most of them around $15-19$ years old (8 children or $53.3 \%$ ), education level are junior high (10 children or $66.7 \%)$, and 7 children (46.7\%) already lived in UPTD institution for 3 years.

By the literature review above we already known that in general there are 4 roles of social worker which are facilitator, educator, community representatives and technical roles. Accordance to street children information needs, those roles would be implemented in various activities. Street children usually do not know where and how to obtained information which they expected according to their needs, so in this case, social worker play their roles to help them finding valid information. The result from attempt to find the role of social worker in developing information needs among street children was elaborate as follows.

a. The Role as Facilitator

As facilitator, social worker provides support for street children to find information they need by being an intermediary in negotiate, giving support, organizing and utilizing available resources in UPTD. To do this role, $13(76.5 \%)$ social workers provide an opportunity for street children to disclose their information needs. The social worker must aware and know the type of information required by the street children, and this study note that the type of information needed by street children are mostly related to their hobbies (such as music, sports) which stated by $9(60 \%)$ children, then information about entrepreneurship by $6(40 \%)$.

According to Jim Ife [13], facilitator play role to uplifting or giving encouragement to individuals, groups and the community to use the potentials resources they owned to increase productivity. They have to providing support to strengthen, recognize and appreciate the value of which is owned, respecting their contributions, work and build consensus with other parties to cooperate in order to develop every potential. The role as facilitator also appear when social worker arrange a discussion with street children about information they needed, therefore it is necessary to build an effective communication between them so the social worker can properly understand which information they needs. Based on the findings known that $8(47.1 \%)$ social worker using a personal approach to establish communication with street children, on the other hand, $9(60 \%)$ children took the initiative to interact through learning activities or when doing some activity with social worker. Social worker sought to know and understand information that street children needs, identify questions to answer the information, and also determine the right resources by strengthening the communication between the social worker and street children. In this research, communications between the social worker and street children in the form of interpersonal communication (face to face) so that the response of street children would be immediately known by the social worker (immediate feedback). Communication intended to make other person understand and knowing about something, also received a conviction, do an activity, and others. The social worker should be communicative, because communicants (street children) and communicator (social worker) have mutual understanding of language and meaning contents of the conversation [14].

Besides that, social worker also arranges communications with other parties such as senior peer social worker (an expert) or with the librarian in UPTD special library to meet the information needs of street children. As it seems from the findings indicate that the strategy undertaken by the social worker to help street children which $13(76.5 \%)$ social worker do some coordination with another peer (senior social worker), and each $2(11.8 \%)$ working together with the librarian or try to find information in another resources (internet). The social worker and street children discussed how to choose information more systematically, how to find the information quickly, where information can be found, provide strategies that can be used to obtain valid information for street children. Based on data findings, shown that another effort taken 
by the social worker to help the street children for more independent in finding information, like $12(70.6 \%)$ social worker teaches street children step by step how to obtain the appropriate information, $3(17.6 \%)$ invite street children to visit the library then asking librarian to help them, and $2(11.8 \%)$ social worker teach directly how to find information via the internet. This is also confirmed by the street children who doing a variety ways to find the information they need, $6(40.0 \%)$ children try to seek information through the internet, $5(33.3 \%)$ children are looking to a variety resources even doesn't know which sources are most correct, and $4(26.7 \%)$ take an easy way from the collection in the library.

The existence of special library in UPTD became one of information centers that can be utilized to develop the potential interest of street children. This library is managed by a librarian who has educational background in library and information science, located on $35 \mathrm{~m}^{2}$ areas, the collection where put in 2 shelves, with 752 titles of books that acquired from partnership with the Library of Surabaya City and grants from the surrounding community. The library operates some services like reading services, circulation services and information search services, even though every year the development of collection just under 5\%. In general, the condition of UPTD special libraries does not meet a standards of special libraries, this conditions also affects the role of social worker in supporting the learning process as well as in facilitate the information needs of street children.

Furthermore, social worker also play facilitator role by providing information media that can be accessed to help children find their information, like $9(52.9 \%)$ social worker prefer using books, print journals, magazines, while $8(47.1 \%)$ select information form digital media (e-books, online journals). The reason why they more prefer choosing printed information media because of the ease to looking for it (29.4\%), more easier and quick access (29.4\%), also their eyes not strong enough to read along on digital screen and considering the ease in storing collection (11.8\%).

\section{b. The Role as Educator}

Another role which social worker can do to developing street children information needs is as educator. They give positive feedback based on their knowledge and experience as well as share ideas with the knowledge and experience of the street children. Some tasks associated with the role of social worker as educators like raising awareness about important information, conveying information and engage in discussion, as well as managed training skill to get right information.

According to $12(70.6 \%)$ social worker, they tried to help street children more aware and independent in the process of finding information, so that they have to teach them a strategy to obtain appropriate information, like visit the library or using the internet. The social worker providing opportunities for children to share their idea, teach them become aware of and consciously using their own strategies to find information, so they can have a great experience. But, sometimes street children already understand the scope of their information need and feel optimistic about the possibility in obtaining the information which suitable with their needs. As 7 (46.7\%) children stated immediately try to find information without any preparation, 5 (33.3\%) determine the topic (or keywords) and $3(20.0 \%)$ asking to the social worker an alternative locations where information can be found.

The main things to be considered by street children when choosing the source of certain information is the resources should be valid and accountable. They have two resources from library and internet. If street children want to find information from UPTD special library they can do it independently because the librarian already teach them how to access the collection by seeing the difference cover color of each collection which shows the classification of a particular subject. Sometimes they also engaged to help librarian arrange the collection so they quite familiar with the collection in library. But, they still need help to find valid information from internet due to their less knowledge and limited access provided by UPTD.
With the help from social worker, street children were able to convey the source of the information that is most relevant to their information needs and be confident in the accuracy of the information source. Regarding the ability of street children to finding relevant information after receiving assistance from the social worker, there are 6 children (40.0\%) who began to find information by determining the right keywords and appropriate strategy, though 9 children $(60.0 \%)$ experiencing difficulties due to no internet access and prefer to choose another strategy. That conditions also have impact on information channels that are frequently accessed by street children is mostly library $(60.0 \%)$. If they need information from the internet, social workers help them to find it from their own personal computer.

The reaction of street children after the information found indicates that $6(40.0 \%)$ children keep it for himself, $5(33.3 \%)$ share the information with others, and each of $2(13.3 \%)$ are not keep the information and even never kept it. However, if the street children not found information that appropriate to their needs, according to $7(46.7 \%)$ they would ask the social worker how to find information quickly, $5(33.3 \%)$ do not try to find further information, $2(13.3 \%)$ postpone to find further information until some friends asking to find information together, and $1(6.7 \%)$ declared doing nothing to find more information.

Social worker assessing whether the information obtained in accordance with the needs, and considering the current of the information obtained by carry out an evaluation of the information that street children found such as $13(76.5 \%)$ social worker evaluates tentatively to determine the compatibility of information which obtained by street children. Besides that, social worker also evaluate whether street children have been discovered or not the information they need, by providing feedback questions (16 social worker), and only $1(5.9 \%)$ who do not pay attention to whether the information is right or not. Evaluations in the field of education is a process of collecting data to determine the extent to which, in any case, and how the educational goals have been achieved, if not achieved it must be known what the cause [15].

In fact, $6(40.0 \%)$ children stated that they found a lot of information, but they need some help to decide which one is most relevant, then $4(26.7 \%)$ children stated that the information they looking for is not fully discovered and need to find in other sources, $3(20.0 \%)$ stated that all information they seek is found and provide benefits for they knowledge and $2(13.3 \%)$ stated that the information they are looking for can't be found and not relevant.

The ability of street children in finding information, tend to be still dependent on social worker help which stated by $12(70.6 \%)$ social worker and only $5(29.4 \%)$ stated that street children were able to determine information that they need, and find out the source of information that can be used. According to street children in UPTD, the main obstacle when finding information is related to their ability in finding the right information stated by 8 $(53.3 \%)$ children, while each of $3(20.0 \%)$ stated because of limited resources in the UPTD library and they are not allowed to access information on the internet, and only $1(6.7 \%)$ who stated that no intents assistance guidance to find the right information.

c. The Role as Community Representatives and Technical Roles These two roles are not so dominant nor influence when social worker helping street children to find information they needs, because this role can be seen from the activities conducted by the social worker which are not directly related with information finding activity. For example how social worker get to know the characteristics of street children by doing some tests to find out the psychological of street children and their family background which stated by $8(47.1 \%)$ social worker.

By this role, social workers also build trust with street children in order to facilitate the consultancy about kinds of good information, where $12(70.6 \%)$ social worker discuss with the street children about kind of information they needs. Social worker also need to know the psychology condition of the children by looking at how 
long the street children had stayed at UPTD, also from the age of street children in order to know his capability to learn something, each stated by $2(11.8 \%)$ social worker. To conduct technical role, social worker have to arrange consultancy where this process usually based on the relationship characterized by mutual trust and open communication, work together in identifying the problem, bringing together private sources to get to know and have the possibility of choosing a strategy that can solve problems that have been identified, and the responsibilities in implementation and evaluation of programs and strategies that have been planned [1617].

\section{Conclusion}

The role of social worker to improving street children information needs is very important, especially as facilitator and educator because $12(70.6 \%)$ social worker stated that the ability of street children in finding information is still dependent on social worker role as facilitator and educator. To support the achievement of valid information, UPTD institution have to provide facilities to support this process such as a complete and vary library collection especially which have related with street children hobbies as the most wanted collection. The condition in UPTD special library really need to be addressed in terms of rooms, collections, service, infrastructure, and also the competency of the librarian to serve valid and complete information for street children.

Besides that, street children also need an alternative information source like digital information media (internet), but it should be provided with close supervision from social worker in UPTD and make an agreement with street children about the purpose of the provision of that media, so the utilization of that media can be controlled.

\section{References}

[1] Data Science Indonesia. Street Children Assistance and Presence Shelter: Are there efforts for a comprehensive mentoring?. 2015. Can be accessed http://datascience.or.id/2015/08/02/pendampingan-anak-jalanankeberadaan-rumah-singgah-adakah-upaya-agar-pendampinganyang-menyeluruh/

[2] Ministry of Social Affairs - Social Development Centre. Social assistance in empowering street children (conception and strategy). 2010. Can be accessed athttp://sdc.depsos.go.id/modules.php?name=News\&file=article \&si $\underline{\mathrm{d}=15}$

[3] Jawapos.com. The number of street children increased to $4.1 \mathrm{mil}$ lion. 2016. Accessed at http://www.jawapos.com/read/2016/03/29/22330/jumlah-anakjalanan-meningkat-jadi-41-juta

[4] Central Bureau Statistics of East Java Province. Percentage of Abandoned Children (Age 5-17 Years). 2012. Accessed at https://jatim.bps.go.id/linkTabelStatis/view/id/230

[5] Mayor of Surabaya, regulation No. 61/2012 on Social Service of Surabaya City.

[6] Decree of the Minister of Social Affairs of the Republic of Indonesia Number: 15 A / Huk / 2010 on General Guidelines for Children's Social Welfare Program, can be accessed at http://storage.jakstik.ac.id/ProdukHukum/Sosial/Kepmensos NO.15.pdf

[7] K. E. Fisher,, S. Erdelez., and L. (E. F.) McKechnie. Theorist of information behavior: "imposed theory". United State of America: Library of Congress-in-Publishing Data; 2005.

[8] M. Gross. Imposed Seeking Information In Public Libraries And School Library Media Centers: A Common Behavior?. Information Research; 2001; 6 (2) Available at: http://InformationR.net/ir/62/paper100.html

[9] Ministry of Social Affairs of the Republic of Indonesia, Glossary Implementation of Social Welfare, can be accessed at https://www.kemsos.go.id/modules.php?name=glosariumkesos\&let $\underline{\text { ter }=\mathrm{a}}$
[10] B. Suyanto. Children Social Issues. Jakarta: Kencana, Prenada Media Group; 2010.

[11] S. Arikunto. Procedure Research: A Practical Approach. Jakarta: Rineka Reserved; 2010.

[12] B. Bungin. Social Research Methodology: The formats of quantitative and qualitative. Surabaya: Airlangga Univercity Press; 2004.

[13] J. Ife. Community Development Cerating, Community, Alternatif Vision Analysis and Pratice, Logman, Dly, Ltd Australia; 1995.

[14] O. U. Effendy. Communication Studies (Theory and Practice). Bandung: PT. Youth Rosdakarya; 2007.

[15] S. Arikunto. Dasar-dasar Evaluasi Pendidikan. Jakarta: Bumi Aksara; 2012.

[16] J. E. Zins., T.R. Kratochwill., \& S. N. Elliot. Handbooks of Consultation service for children. San Fransisco: Jossey-Bass; 1993.

[17]E. Suharto. Social Assistance in the Development of Persons, paper; 2002. Accesed in http://www.policy.hu/suharto/modul a/makindo 31.htm 